\title{
Proximate Analysis of Selected Non Woody Biomass
}

\author{
P.A. Bhavsar ${ }^{1}$, M.H. Jagadale ${ }^{2 *}$, Y.P. Khandetod ${ }^{1}$ and A.G. Mohod $^{1}$ \\ ${ }^{1}$ College of Agricultural Engineering and Technology Dapoli, Maharashtra, India \\ ${ }^{2}$ Central Institute of Agricultural engineering, Bhopal-462038, India
}

*Corresponding author

\section{A B S T R A C T}

\section{Keywords \\ Biomass, Fuels, Renewable fuels \\ Article Info \\ Accepted: \\ 20 August 2018 \\ Available Online: \\ 10 September 2018}

Biomass based fuels are considered as renewable fuels. Biomass fuels are considered better in comparison to fossil fuels in term of their carbon neutral features. Biomass combustion has been widely recognized as key thermal conversion technology for residues in biomass based power plants. This paper deals with proximate analysis of selected non woody biomass viz. dry grass, mango leaves, cashew leaves, rice husk, rice bran, cow dung and waste flour.

\section{Introduction}

Biomass is renewable organic matter derived from trees, plants, crops or from human, animal, municipal and industrial wastes. Biomass can be classified into two types, woody and non-woody. Woody biomass is derived from forests, plantations and forestry residues.

Non-woody biomass comprises agricultural and agro industrial residues and animal, municipal and industrial wastes.In order to use any biomass as a fuel, proximate analysis of fuel is important parameter for knowing the suitability and quality of fuel. It included determination of moisture content, volatile matter, ash content and calculation of fixed carbon on percentage weight basis.

\section{Materials and Methods}

Materials including locally available dry grass, dry mango leaves, dry cashew leaves, rice husk, rice bran, dry dung were manually collected from university experimental plots, in Dr. Balasaheb Sawant Konkan Krishi Vidyapeeth, Dapoli and waste flour was collected from local flourmills. Selected biomass i.e. mango leaves, cashew leaves and grass was converted it into powder form by using shredder having capacity of $5 \mathrm{~kg}$ and was sieved through $2 \mathrm{~mm}$ size sieve to get the desired size of raw material.

\section{Proximate analysis}

The proximate analysis was carried out by using standard procedure as follows: 


\section{Moisture content}

The moisture content of biomass was measured by oven dry method. Initially the sample with the known weight was kept in oven at $+105^{\circ} \mathrm{C}$ till the constant weight. Then the oven dry sample was weighed (ASTM D3173). The moisture content of sample was calculated by following formula.

Moisture content $(\% \mathrm{wb})={ }^{\frac{W_{2}-W_{3}}{W_{2}-W_{1}}}$ X 100 (1)

\section{Volatile matter}

The dried sample left in the crucible was covered with a lid and placed in muffle furnace, maintained at $950 \pm 20{ }^{\circ} \mathrm{C}$ for 7 minutes (ASTM D-3175). The crucible was cooled first in air, then inside desiccators and weighed again. Loss in weight was reported as volatile matter on percentage basis.

Volatile Matter $(\%)=\frac{W_{3}-W_{4}}{W_{2}-W_{1}}$ X $100(2)$

\section{Ash content}

The residual sample in the crucible was heated without lid in a muffle furnace at $700^{\circ} \mathrm{C}+50^{\circ} \mathrm{C}$ for one half hour (ASTM D- 3174). The crucible was then taken out, cool first in air, then in desiccators and weighed. Heating, cooling and weighing was repeated, till a constant weight obtained. The residue was reported as ash on percentage basis.

Ash Content $(\%)={ }^{\frac{W_{5}-W_{1}}{W_{2}-W_{1}}}$ X $100(3)$

\section{Fixed carbon}

The fixed carbon content was calculated by applying the mass balance for the biomass sample.
Fixed Carbon $(\%)=100-\%$ of $(\mathrm{MC}+\mathrm{VM}$ $+\mathrm{AC})(4)$

Where,

$\mathrm{FC}=$ Fixed carbon, $(\%)$

$\mathrm{MC}=$ Moisture content, $(\%)$

$\mathrm{VM}=$ Volatile matter, $(\%)$

$\mathrm{AC}=$ Ash content,$(\%)$

\section{Results and Discussion}

\section{Proximate analysis of selected biomass}

The raw non woody biomass used for briquetting was dry grass, dry mango leaves, dry cashew leaves, rice husk, rice bran, dry dung and waste flour. In proximate analysis moisture content, volatile matter, ash content and fixed carbon of these selected non woody biomass material were calculated as per given in table 1 and depicted in Figure 1.

The moisture content of dry grass, dry mango leaves, dry cashew leaves, rice husk, rice bran, dry dung and waste flour were found to be 10.63 per cent, 8.17 per cent, 10.86 per cent, 7.2 per cent, 8.5 per cent, 7.47 per cent and 11.96 per cent, respectively. Moisture content was more in waste flour due to higher lignin content. The volatile matter of dry grass, dry mango leaves, dry cashew leaves, rice husk, rice bran, dry dung and waste flour were found to be 65.08 per cent, 64.4 per cent, 65.33 per cent, 61.8 per cent, 86.33 per cent,60.77per cent and 59.25 per cent, respectively.

The volatile matter is more in rice bran because of higher cellulose content. The ash content in dry grass, dry mango leaves, dry cashew leaves, rice husk, rice bran, cow dung and waste flour were found to be 8.9 per cent, 11.25 per cent, 6.9 per cent, 16.4 per cent, 2.93 per cent, 15.35 per cent and 13.82 per cent, respectively. 
Table.1 Calculated proximate analysis of selected biomass

\begin{tabular}{|l|l|l|l|l|l|}
\hline $\begin{array}{l}\text { Sr. } \\
\text { no. }\end{array}$ & Biomass sample & $\begin{array}{l}\text { A verage } \\
\text { moisture } \\
\text { content }\end{array}$ & $\begin{array}{l}\text { Average } \\
\text { Volatile matter }\end{array}$ & $\begin{array}{l}\text { Average } \\
\text { content }\end{array}$ & $\begin{array}{l}\text { Asserage } \\
\text { Fixed } \\
\text { Carbon }\end{array}$ \\
\hline 1 & Dry grass & $\mathbf{1 0 . 6 3}$ & $\mathbf{6 5 . 0 8}$ & $\mathbf{8 . 9}$ & $\mathbf{1 5 . 3 5}$ \\
\hline 2 & Mango leaves & $\mathbf{8 . 1 7}$ & $\mathbf{6 4 . 4}$ & $\mathbf{1 1 . 1 3}$ & $\mathbf{1 5 . 9}$ \\
\hline 3 & Cashew leaves & $\mathbf{1 0 . 8 6}$ & $\mathbf{6 5 . 3 3}$ & $\mathbf{6 . 9}$ & $\mathbf{1 6 . 8 7}$ \\
\hline 4 & Rice Husk & $\mathbf{7 . 2}$ & $\mathbf{6 1 . 8}$ & $\mathbf{1 6 . 4}$ & $\mathbf{1 4 . 6}$ \\
\hline 5 & Rice bran & $\mathbf{8 . 5}$ & $\mathbf{8 6 . 3 3}$ & $\mathbf{2 . 9 3}$ & $\mathbf{2 . 2 3}$ \\
\hline 6 & Dry dung & $\mathbf{7 . 4 7}$ & $\mathbf{6 0 . 7 7}$ & $\mathbf{1 5 . 3 5}$ & $\mathbf{1 6 . 4 4}$ \\
\hline 7 & Waste flour & 11.96 & $\mathbf{5 9 . 2 5}$ & $\mathbf{1 3 . 8 2}$ & $\mathbf{1 4 . 9 6}$ \\
\hline
\end{tabular}

Fig.1 Proximate analysis of selected non woody biomass

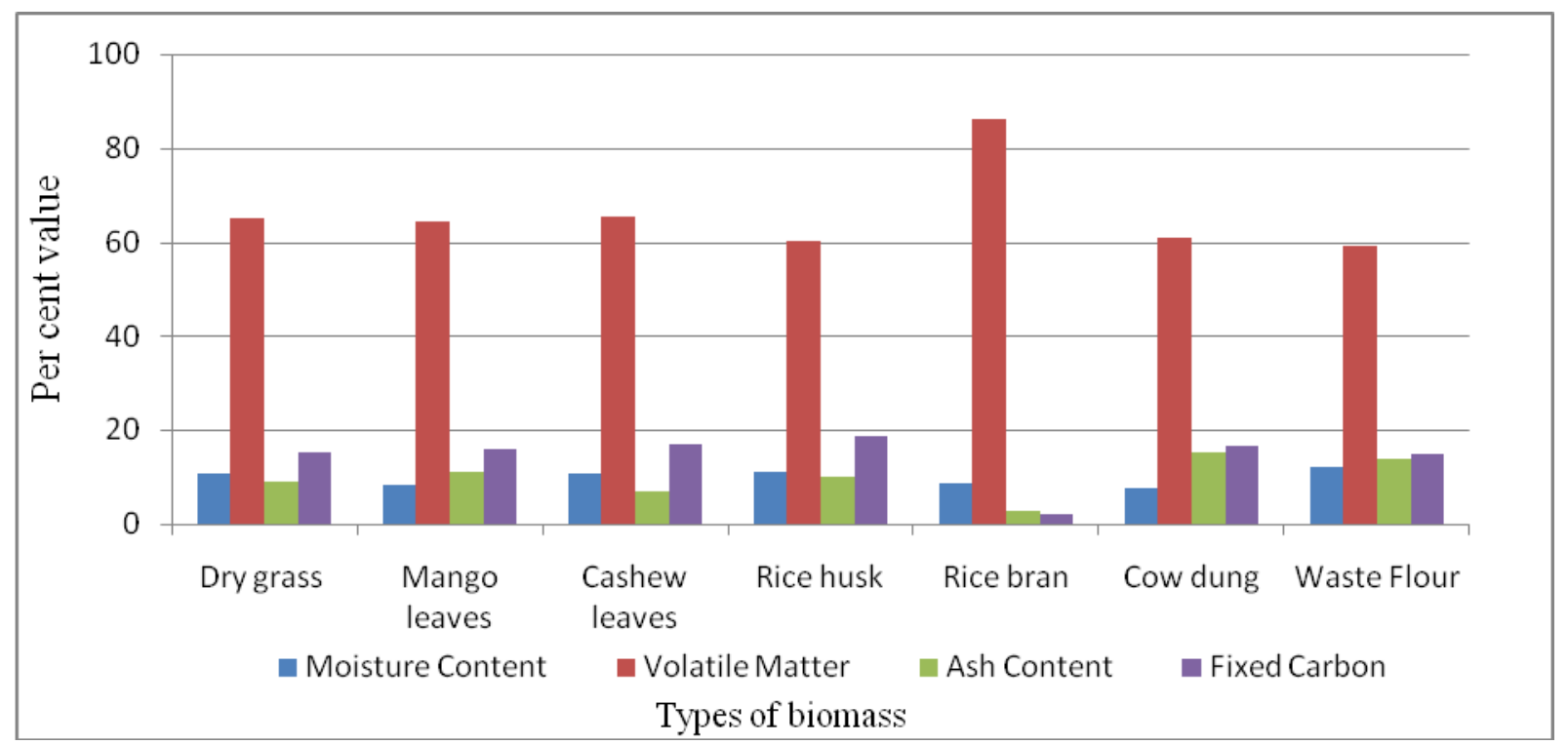

The fixed carbon was calculated to be 15.35 per cent for grass, 15.90 per cent mango leaves, 16.87 per cent for cashew leaves, 14.60 per cent for rice husk, 2.23 per cent for rice bran, 16.44 per cent in dung and 14.96 per cent in dry dung.

It was observed that fixed carbon was found highest in dry cashew leaves as compared to dry grass, dry mango leaves, rice husk, rice bran, dry dung and waste flour. The higher carbon content could be help for increasing energy in terms of calorific value for making briquettes. The ash content was found lowest in rice bran $(2.23 \%)$. While dry grass, dry mango leaves, dry cashew leaves, rice husk, rice bran, dry dung and waste flour were approximately 10 per cent, this indicated that the material was suitable for briquetting. The moisture content of all raw biomass for making briquettes was found in the range of 7.2 to 12 per cent. It was found within acceptable limit (below 15\%) for making briquettes and for thermal application of briquettes.

The selected biomass is not having major alternative use, and it has high calorific value, 
easy availability and low nutritive value. Among the selected raw biomass cashew leaves had maximum fixed carbon i.e. 16.87per cent

\section{References}

Birwatkar V.R., Y.P. Khandetod, A.G. Mohod and K.G. Dhande 2014. Physical and Thermal Properties of Biomass Briquetted Fuel. Ind. J. Sci. Res. And tech. 2014 2(4):55-62.
Dahariya K. 2013. Estimation of Power Generation Potential of Agricultural Based Biomass Species and CoalBiomass Mixed Briquettes. M.Tech. thesis, Department of Mechanical Engineering, National Institute of Technology Rourkela, Orissa.

Sahu G., V. Singore and S. Dongre 2014. Estimation of Power Generation of Non-Woody Biomass. Ind. J. Sci. Res. Index Copernicus Value (2013): 6.14 | Impact Factor (2013): 4.438

\section{How to cite this article:}

Bhavsar, P.A., M.H. Jagadale, Y.P. Khandetod and Mohod, A.G. 2018. Proximate Analysis of Selected Non Woody Biomass. Int.J.Curr.Microbiol.App.Sci. 7(09): 2846-2849. doi: https://doi.org/10.20546/ijcmas.2018.709.353 